\title{
Editorial note: Forum on the Anthropocene
}

\section{Ato Quayson}

This forum on Ian Baucom's “History $4^{\circ}$ : Postcolonial Method and Anthropocene Time" (published under the section on paradigms in PLI 1.1, 2014) is the first of a series that the journal will be featuring to highlight paradigmatic pieces in the field that in the opinion of the editorial board shed light on significant new theoretical orientations. The forum here brings together short contributions by Dipesh Chakrabarty, Karen Pinkus, and Tim Morton, three of the most significant voices currently working on ecocentrism and the Anthropocene to share their reflections on Baucom's essay. It is hoped that in combination, the paradigms essays and their attendant forums will generate further debate about the core issues raised in them. 